\title{
住都公団境界層風洞の基本性能 \\ Basic performance of the boundary layer wind tunnel belonging to Housing and Urban Development Corp.
}

上江洲 清*1

Kiyoshi UESU

\section{SUMMARY}

A closed - circuit type boundary layer wind tunnel has been constructed at Hachiohji Laboratory, Housing and Urban Development Corp.. It is the multipurpose wind tunnel which can be used for many researches on wind engineering. The working section of the wind tunnel is $2.1 \mathrm{~m}$ in height, $2.8 \mathrm{~m}$ in width and $17.5 \mathrm{~m}$ in length. The range of wind speed is from 0.5 to $30.0 \mathrm{~m} / \mathrm{s}$ and the uniformity of mean wind speed and the turbulence intensity in the working section are within $\pm 1.0 \%, 0.3 \%$ respectively. The characteristics of the boundary layer flow made by spires and roughness blocks in the wind tunnel are also described in this paper.

\section{はじめに}

昨年 (平成6年) 夏, 住宅・都市整備公団の試験研究 所（八王子試験場）に大型境界層風洞が完成した。

公団八王子試験場には, 昭和 51 年, コンクリートPC 板接合部の防水性を試験するための風雨発生装置の送 風機を転用した風洞実験装置が設置され, 昭和 55 年以 降公団が開発する住宅団地の主に風環境を対象とした 風洞実験を実施してきた。

今回の風洞の新設は, 設置後約 20 年が経過して機械 装置の更新時期を迎えていること又, この実験装置が元々 風洞として建設されたものではないため部分的な改修 や改善では現在の各種風洞実験に要求される風洞内気 流が作成できないことなどのため, 風洞建屋を除き全面
的な更新を行ったものである。

以下, 新風洞の基本性能について報告する。

\section{1. 新風洞の基本コンセプト}

1. 1 条件

新風洞を計画するについて与えられた条件には次の ようなものがある。

建 設 地 公団八王子試験場内の既存風洞の設置場所と する。

風洞建屋 既存風洞建屋をできるだけ活用する。

以上の 2 点と建設予算, 完成時期を除き他には新風洞 を計画する上での条件は特になかった。但し, 既存の風 洞建屋が隣地との境界に近いため下屋の增築計画に際

* 1 住宅・都市整備公団 試験研究所 専門役 Senior Specialist, Research Inst., Housing and Urban Development Corp. (原稿受理 : 1995年6月30日) 
しては平面訃画上の制約条件となった。

1. 2 コンセプト

新風润は，次のようなコンセプトに基づき計曲された。

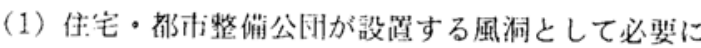

して㤋（最適）な規模，性能を份すること。

公四の社会的な役割や, 性格を踏まえ又, 㼋究所の組 織形態やマンパワーの実態から, 風洞の替模は, 無閐に 大型化を日指すのではなく，扱いやすい，最適な規模・ 性能を求めることにした。

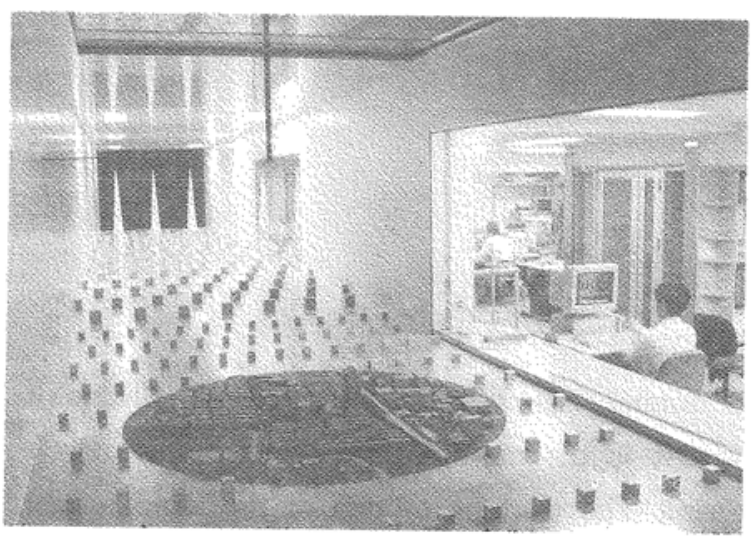

Photo. 1 風洞内観

(Interior of the working section)
（2）实験に必紧とされる良好な風洞気流を実現する。 風洞内父流は, 各種の風洞実験を行う上で必要な性能 条件を満足しなければならない。このために必要な測 定胴の艮さや縮流比等は十分な距離・值を確保するよ う努めた。その結果, 叫存の建屋内に風路を納めること は不订能であったため, 既存建屋の耐力壁 2 枚を撤去し、 風路はここを貫通して半分以上を建屋の外に出した。こ のため, 建屋の外の風路を围う下屋を增筑することとし た。

（3）使い勝手が艮い実験施設と，快適な執務スペースを 同時に実現する。

当然のことであるが, 䒠験装置・設俑としては, 使い 易いことを第一に考える。徉来二次的に考えられてい たきらいのある計测・執務スペースは風路, ターンテー ブル（下）等への作栄動線を配感した位罩とし又, 計测 機器の設㨁位筧と所要スペースを考虑して十分な空間 を確保し快適な執務愣境の実現に意を用いた。

更に, 実験の準備作業が主にターンテーブル下の空間 で行われることから風路下の作整空間の確保及び執務 室等との断面関係にも紐心の注意を払った。

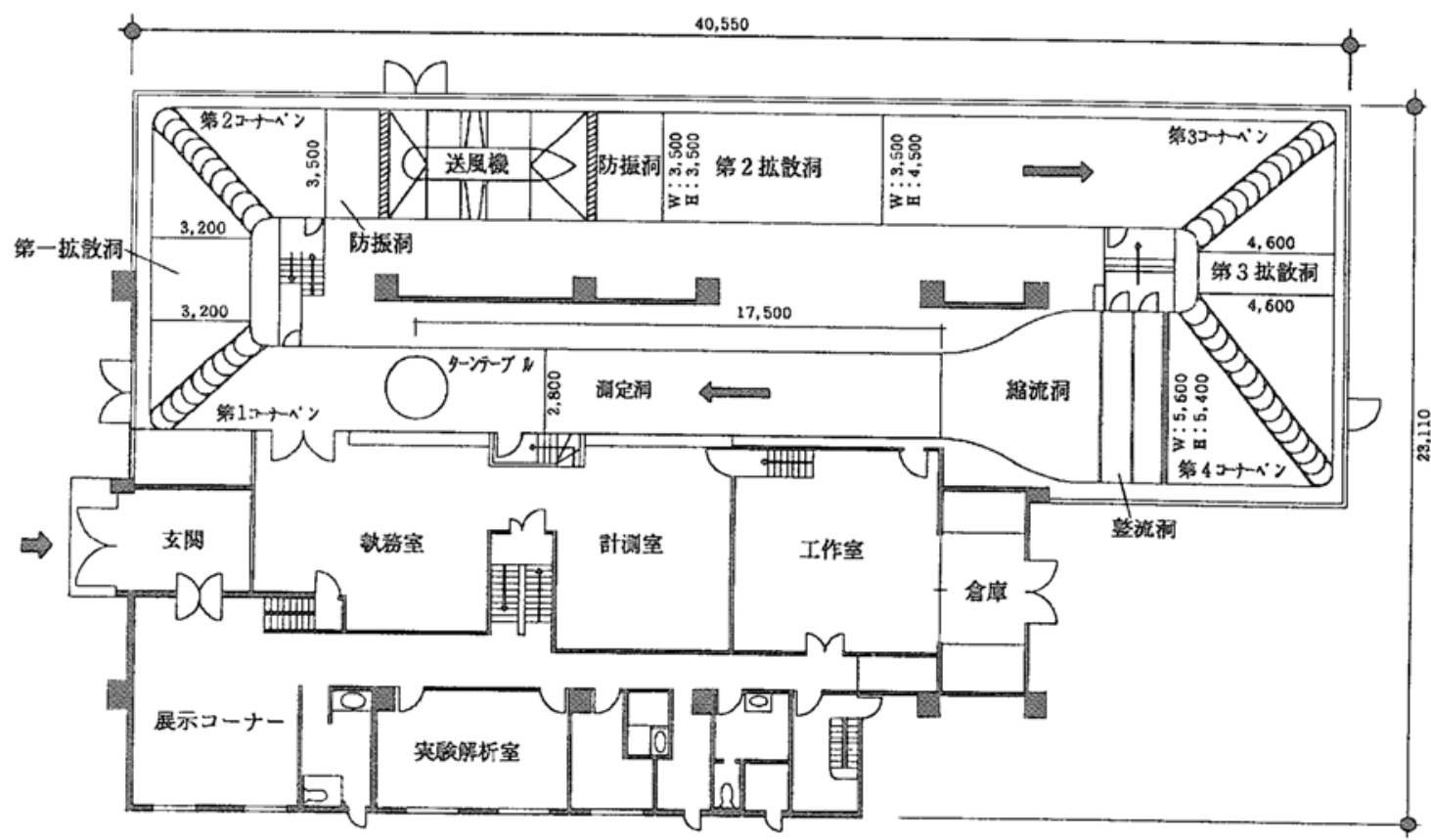

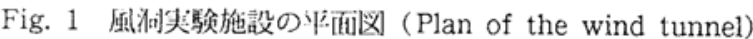




\section{2. 風洞実験施設}

\section{1 概要}

風洞実験施設の平面図をFig. 1に, 主要性能の諸元を Table 1に示す。風洞实験施設は, Fig. 1に示すとおり 長辺方向が, $40.55 \mathrm{~m}$, 短辺方向が $23.1 \mathrm{~m}$ の平面形を有 し, 北側の約半分が風路, 南側半分が, 執務室, 計测室, 工作室, 倉庫等の諸室となっている。

Table 1に示すとおり風洞形式は回流型境界層風洞で あり, 測定胴の幅は, $2.8 \mathrm{~m}$ 高さ $2.1 \mathrm{~m}$ 長さ $17.5 \mathrm{~m}$ である。 風速笘囲は, 测定胴ターンテーブル中心で $0.5 \sim 30 \mathrm{~m} / \mathrm{s}$ の間, 連続可变である。

Table 1 風洞の主要性能諸元

(Main specifications of the wind tunnel)

\begin{tabular}{|c|c|}
\hline 風洞形式 & 回流型境界原風洞 \\
\hline 風路絰延长 & $86 \mathrm{~m}$ \\
\hline 測定䏤断面 & 幅: $2.8 \mathrm{~m}$ 高さ: $2.1 \mathrm{~m}$ 長さ $: 17.5 \mathrm{~m}$ \\
\hline 縮流比 & 5.12 \\
\hline 風速笣用 & $0.5 \sim 30 \mathrm{~m} / \mathrm{s}$ (ターンデープルゆ心) \\
\hline 風速分布 & $\begin{array}{l}1 \% \text { 以下（風速 } 5 \sim 15 \mathrm{~m} / \mathrm{s} \text {, 境界的䉏缃を } \\
\text { 除く） }\end{array}$ \\
\hline 乱れの強さ & $0.5 \%$ 以内 (同上) \\
\hline 送風機 & 口径 $\phi 3.55 \mathrm{~m}$ \\
\hline 送風機用電䣦樹 & 真流雵動機 $200 \mathrm{~K}$ 目 \\
\hline
\end{tabular}

Table 2 送風㙨及び電動機の仕梯

(Specifications of the Fan and the Moter)

\begin{tabular}{|c|c|c|}
\hline & 項目 & 仕样 \\
\hline \multirow[t]{4}{*}{ 送風機 } & 形式 & 朝流一段式 \\
\hline & 口圣 & 3. $55 n$ \\
\hline & 翼の枚数 & 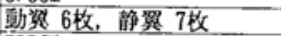 \\
\hline & 息の材幦 & FRP依 \\
\hline \multirow[t]{5}{*}{ 霫䦽機 } & 形式 & 他力䢎風型直流電䣦機 \\
\hline & 出力 & $200 \mathrm{KV}$ \\
\hline & 最大回秐數 & $1150 \mathrm{rpm}$. \\
\hline & 回䎐数制御 & サイリスタレオナード方式 \\
\hline & ファン路䣦 & Vベルト政動方式 \\
\hline
\end{tabular}

Table 3 ターンテーブル装置の仕様

(Specifications of the turn table device)

\begin{tabular}{|c|c|}
\hline 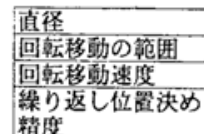 & $\begin{array}{l}\phi 2.0 \mathrm{~m} \\
\pm 360 \text { deg. } * \mathrm{~N} \text { (無制限) } \\
4 \mathrm{rpm} . \\
\pm 0.1 \text { deg. } / 360 \text { deg. }\end{array}$ \\
\hline 上下移動の笓团 & 上方向: $400 \mathrm{~mm}$ F方向 : $200 \mathrm{~mm}$ \\
\hline
\end{tabular}

Table 4 トラバース装置の仕様

(Specifications of the traverse device)

\begin{tabular}{|c|c|c|}
\hline \multirow[t]{4}{*}{ 移動䈥囲 } & X㑲（風路韩） & $\begin{array}{l}\text { ターンテーブル中心から } \\
\pm 1,500 \text { n }\end{array}$ \\
\hline & Y軸（風路直交朝） & $\begin{array}{l}\text { ターンテープル中心から } \\
\pm 1,100 \mathrm{mn}\end{array}$ \\
\hline & 2朝 & 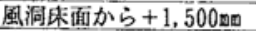 \\
\hline & $\theta$ 㘿 (2朝の[可畭) & \pm 360 deg. \\
\hline \multirow[t]{2}{*}{ 移動速度 } & X, Y,Z朝 & $1,500 \mathrm{mn} / \mathrm{min}$. \\
\hline & $\theta$ 朝 & 60rps. \\
\hline \multirow{2}{*}{$\begin{array}{l}\text { 繰り返し位置 } \\
\text { 決め精度 }\end{array}$} & X,Y,Z朝 & $\pm 0.1 \mathrm{~nm} / \mathrm{m}$ \\
\hline & $\theta$ 韩 & \pm 0.1 deg. $/ 360$ deg. \\
\hline
\end{tabular}

\section{2 送風機及び電動機}

Table 2 に送風機及び電動機の仕様を示す。送風機 は, 口径 $\phi 3.55 \mathrm{mFRP}$ 製の可変ピッチ動翼 6 枚静翼 7 枚 である。電動機は, $200 \mathrm{KW}$ の直流電動機を使用し, フ アンの駆動にはV Vベルトを使用している。

\section{3 風路}

風路は測定胴を既存建屋内に収容し他の部位は下屋を 增築してその中に納めている。風路が執務室と計測室 に接する間仕切り壁は, 風路の側壁を兼ねている。この 側壁には, 執務室と計測室に各一ヶ所大型ガラス (幅: 3.5 $\mathrm{m}$ 高さ $: 1.6 \mathrm{~m})$ がはめ込まれ，風洞内の監視がそれぞ

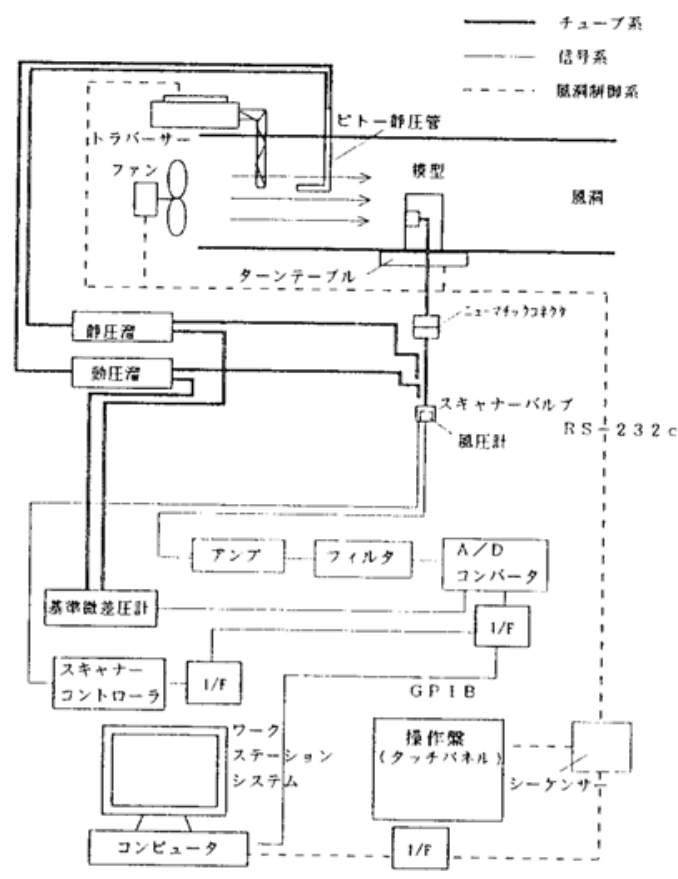

Fig. 2 風洞制御・風王計測システム

(Block diagram of the wind tunnel control and wind pressure measuring systems)

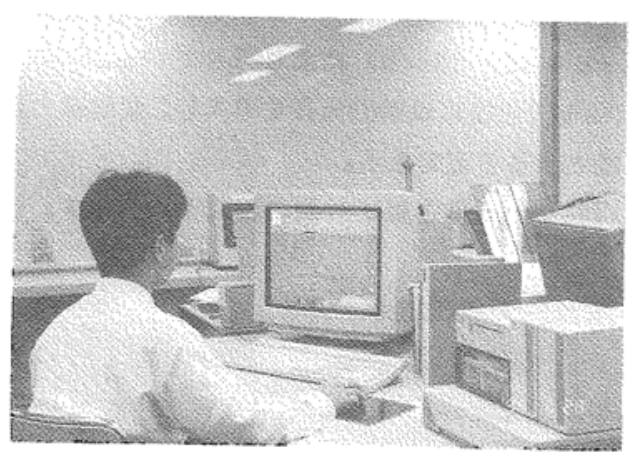

Photo. 2 風洞制御装置

(Control devices of the wind tunnel) 
れの部屋から容易に行えるようになっている。

風路を構成する各部位のうち, 送風機部のケーシング 及び縮流胴の構造は銅製とし, その他の風路各部の床, 壁，天井は，鉄骨造を骨組みとした合板製である。

第二㧙散胴は，高さのみ $3.5 \mathrm{~m}$ から $4.5 \mathrm{~m}$ へ增加してい る。

测定胴は幅が $2.8 \mathrm{~m}$ 离さが $2.1 \mathrm{~m}$, 縮流胴の終端からター ンテーブル中心までの長さが $17.5 \mathrm{~m}$ である。

整流胴にはハニカムが一枚とステンレス製整流金網 (線 径 $0.27 \mathrm{~mm}, 20$ メッシュ）が二枚が設けられている。

2. 4 ターンテーブル・トラバース装置

執務空前面の测定胴に電動昇降機能（手動微調整機構 付）を有する直径 $2.0 \mathrm{~m}$ のターンテーブル装置がある。 ターンテーブル装置の仕様を Table 3 に示す。

ターンテーブル設置筒所の天井面には風洞内気流へ与 える影響が最も小さいと考えられる外装式のトラバー ス装㯰が設けられている。この装置では, 風洞内に現れ る部材は, 䖝速計を支持する外径 $40 \mathrm{~mm}$ のポールのみで ある。トラバース装置の仕様をTable 4 に示す。

2. 5 風洞制御・データ計测システム

送風機, ターンテーブル, トラバース装置はシーケン サーにより制御される。各装置の制御操作は, 共通の操 作盤 (液晶画面のタッチパネル) 若しくは, ワークステー ションにより行う。制御対象装虽の選択や各種の設定 は、ディスプレイ画面に表示されるメニュー项目を選択 し, 設定倬を人力する方式であり, 設定内容の確認や各 装置の現状確認等が容易に行えるものである。

本風湖でのデー夕計测は, 現在, 高層建物の建設等に 伴う風環境予測を行う際必妏となる風速（建物周辺気 流）計測と空ガラスや建県等の高原建物外装材の設計 用椑佰重を設定する際必要となる外圧（風圧）係数の 部测である。

風速の部测には， $128 \mathrm{ch}$ の多点風速計を用いている。 風罒:の部測は，8ch同時のスキャニング方式（最大测定 点数: $8 * 48=384 \mathrm{ch})$ により行っている。

消, 平成 7 作度には動的天科を棌入し、变動風力計测 を呿とする能定である。

Fig. 2 に盾洞例御と風圧計测のシステムを示す。

3. 風洞内気流の性状

3. 1 一様流0場合

(1) 平均風速比分有

風洞内風速（测定高さ：蚛路床上 $1.2 \mathrm{~m}$, 以下同栚）が $10 \mathrm{~m} / \mathrm{s}$ の坳命のターンテーブル中央位置における風路
直交断面の平均風速分布をFig. 3 に示す。

図中の数値は, 断面中央位置における風速を基準とし た各点の風速比である。床面近傍測定点を除き風速の 比は, $1 \pm 0.01$ 程度の籁困に納まっている。

(2) 乱れの強さの分布

風洞内風速が $10 \mathrm{~m} / \mathrm{s}$ の場合のターンテーブル中央位 置における風路直交断面の乱れの強さの分布をFig. 4 に示す。床面境界層の範囲外の测定点では，ほぼ $0.3 \%$

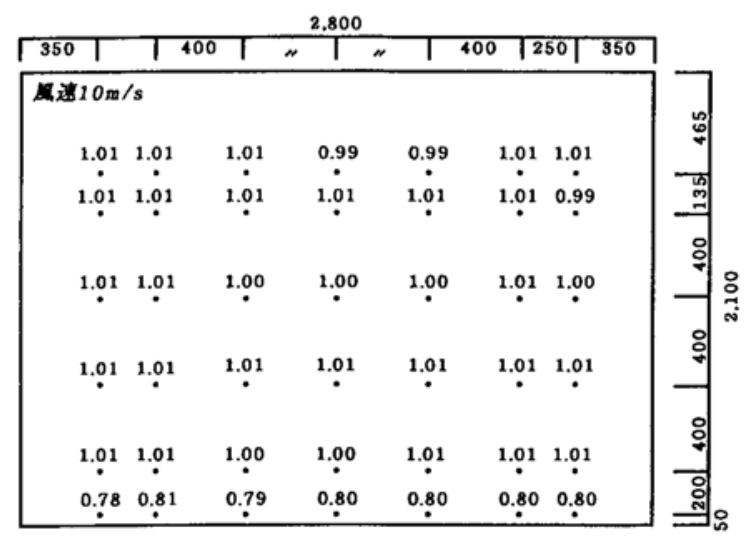

Fig. 3 ターンテーブル中央位置での風速分布 (Distribution of mean wind speed ratio at the working section)

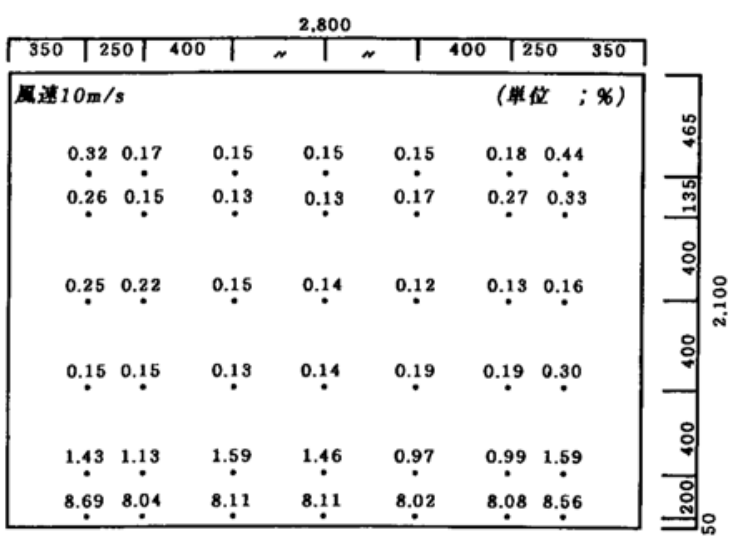

Fig. 4 ターンテーブル中央位置での乱れの強さの分布 (Distribution of turbulence intensity at the working section)

Table 5 スパイヤの形状・寸法

(Shape and size of the spires)

\begin{tabular}{|c|c|c|c|c|}
\hline \multirow[t]{2}{*}{ 種別 } & \multicolumn{3}{|c|}{ スパイヤの形状 } & \multirow[t]{2}{*}{ 目標のべき指数 } \\
\hline & $L(\mathrm{~mm})$ & $\mathrm{B}(\mathrm{mn})$ & $B(n n)$ & \\
\hline I & 500 & 1500 & 273 & $1 / 2 \sim 1 / 3$ \\
\hline II & 520 & 1557 & 237 & $1 / 4 \sim 1 / 5$ \\
\hline III & 545 & 1635 & 169 & $1 / 6 \sim 1 / 7$ \\
\hline
\end{tabular}


以下の値になっている。

(3) 静圧分布

測定部での平均風速が $10 \mathrm{~m} / \mathrm{s}$ の場合の風路各部にお ける圧力分布をFig. 5に示す。静圧の測定位置は, 風路 中央床上 $1.00 \mathrm{~m}$ であり, 基準圧は室内圧（工作室内に圧 力溜を設けた）である。

同図によればターンテーブル位置において約 $2 \mathrm{mmAq}$ の負の静圧が生じており,この值が風速の增加に伴い增 大することが分かった。負圧の存在は実験を実施する 上で不都合な事热を引き起こすことがあるため, 第二コー ナーベーンに取り付けられた飛散防止ネットを利用し て風路断面の一部を閉塞し,ターンテーブル位置の静圧 值を調整した。調整後の風路各部の静圧値をFig. 6 に
示す。

又, ターンテーブル位圈における静圧值を各風速毎に Fig. 7 に示した。平均風速が5 20m/sの範囲におい て調整後の静圧估はほほ大気圧（室内圧）と等しくな っている。

この方法による静圧調整では閉塞部での圧損発生によ り測定部の最大風速は低下する。本風洞の場合最大風 速 $30 \mathrm{~m} / \mathrm{s}$ の要求仕㥞に対し送風（電動）機の能力に余 裕があったためこのような措置を採ることができた。

Fig. 7には，参考として静圧調整を行わない場合の測 定結果も示している。

（4）送風機の運転に伴う風路内温度の上昇 测定胴における風速が $20 \mathrm{~m} / \mathrm{s}$ の状態で送風機を 8 時

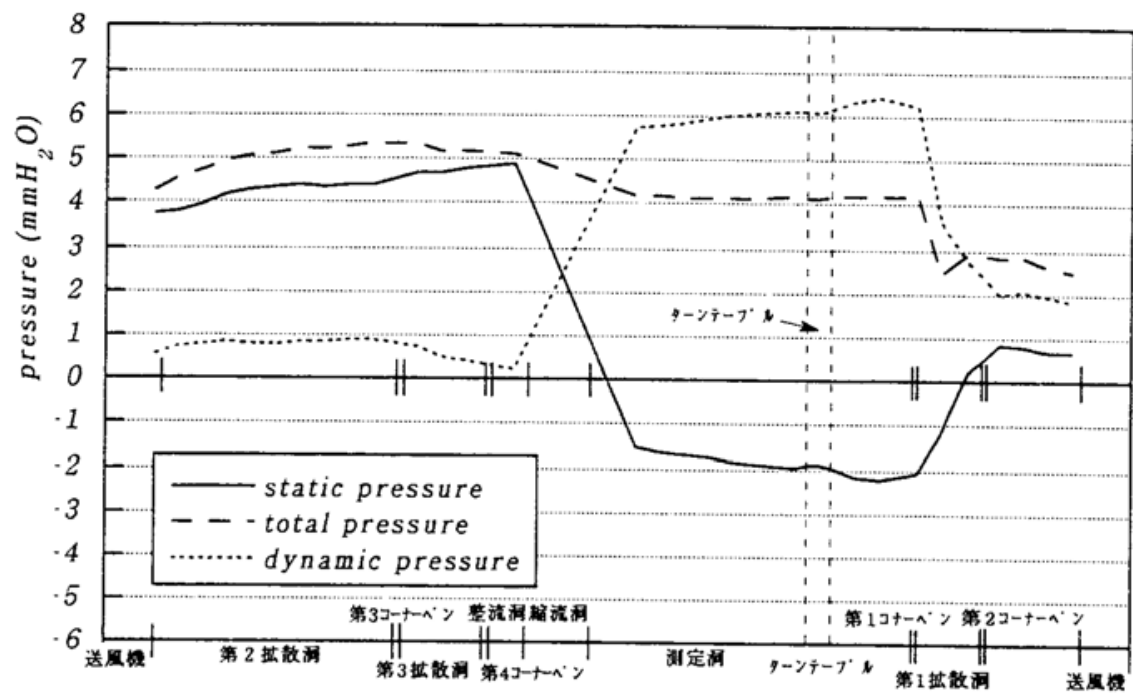

Fig. 5 風路各部における圧力分布（静圧調整前）

(Distribution of pressure along the wind tunnel)

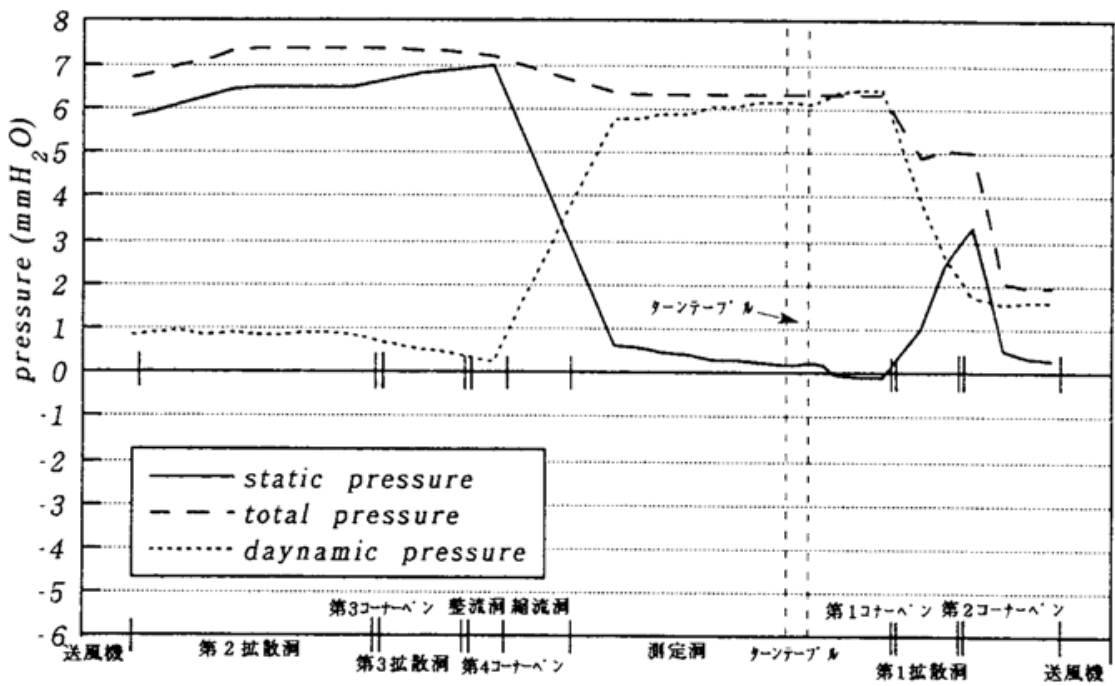

Fig. 6 風路各部における圧力分布（静圧調整後）

(Distribution of pressure along the wind tunnel) 
間連続速転したときの風路内の温度変化を外気温の変 化と共にFig. 8に示す。風路内の温度は, 送風機の速転 開始後, 外気温度の上昇と共に上昇し, 外気温度が低下 後も上最を䋁けるが, 速転開始の約 6 時間後に $33.5^{\circ} \mathrm{C}$ で 半衡状热になった。風路内の潞度上昇勾配は最大 $1.8^{\circ} \mathrm{C} /$ 時であった。

3. 2 境界層流の作成

（1）境界層作成方法

寒験に使用する境界層流を作成するためFig. 9 に示 すスパイヤとFig. 10に示すラフネスブロックを作成し た。スパイヤの形状・寸法は目標とするべき指数にた いしH.P.A.H.Irwin の提案 ${ }^{1}{ }^{2}$ を参考として Table 50 とおり設定した。

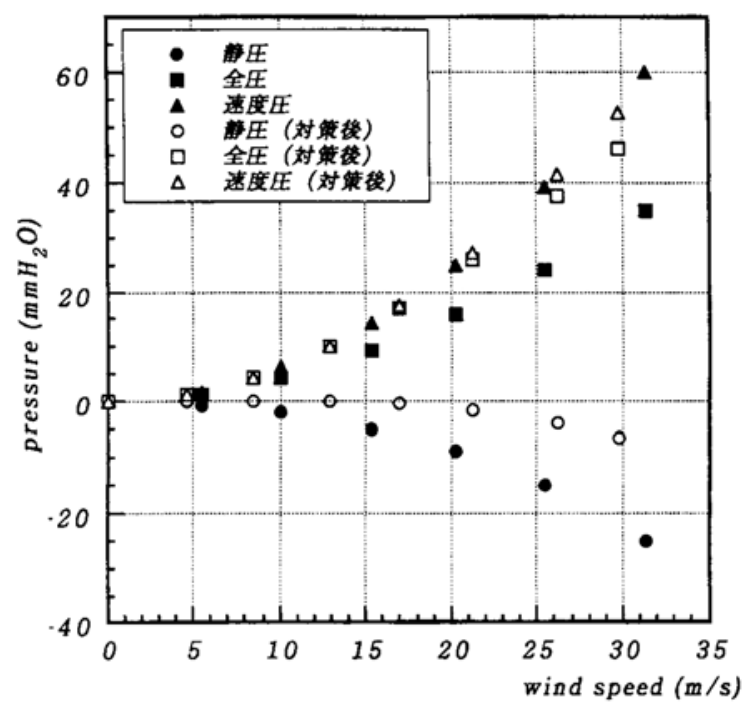

Fig. 7 各俰速隹の静厓值

(Variation of pressure with wind speed at the working section)

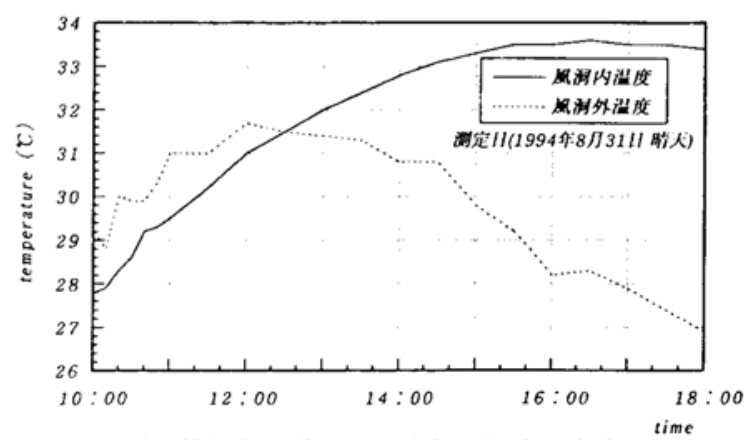

Fig. 8 送慅機速侄に伴う風路内部の温度の変化 (Variation of the temperature in the wind tunnel during the fan work)
（2）気流の特性

1) 気流のプロファイル

平均風速の鉊直分布のべき指数が $1 / 4$ の場合のスパ イヤとラフネスブロックの配置をFig. 11 に示す。 実験風速が $10 \mathrm{~m} / \mathrm{s}$ の時この配置により得られる平均風 速と乱れの強さの鉛直分布をFig. 12 に示す。図中の実 線は, 境界屏高さを $1200 \mathrm{~mm}$ とし, べき指数を $1 / 4$ と して引いた曲線である。乱れの強さは, 模型縮尺を $1 /$ $400 \sim 1 / 500$ とした時, 建築学会荷重指針式 ${ }^{2)}$ と良い対 応を示している。

2）変動風速のパワースペクトル密度

風速が $10 \mathrm{~m} / \mathrm{s}$, べき指数が $1 / 4$ の場合のターンテー ブル中火位置（测定高さ：7〜100cm）における変動風
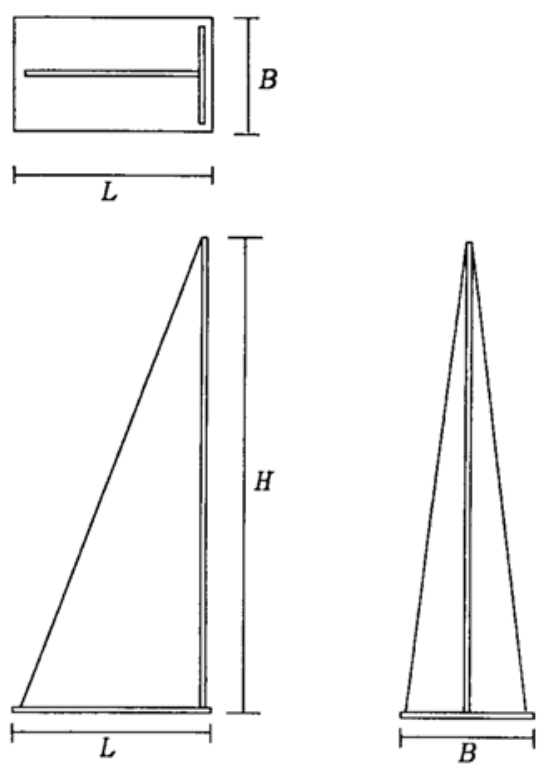

Fig. 9 スパイヤの形状

(Shape of the spires)

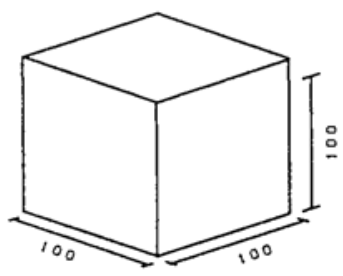

ラフネス大

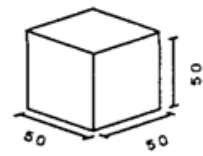

ラフネス小

Fig. 10 ラフネスブロックの形状

(Shape of the roughness blocks) 
速のパワースペクトル密度をFig. 13に示す。スペクト ル形状は, 各高さ共概ねカルマン型に一致している。

3）乱れのスケール

同じく風速が $10 \mathrm{~m} / \mathrm{s}$, べき指数が $1 / 4$ の場合のター ンテーブル中央位置における乱れのスケールを周波数 が0のパワースペクトルの值から求めた。縮尺率が 1 ～
300,1／400及び1／500の三つのケースについて乱れ のスケールの高さ方向分布をFig. 14 に示す。乱れの スケールは報告されている自然風の観測結果と近似し た傾向を示している。同図には, 参考として建築学会の 荷重指針 ${ }^{2)}$ に示される式の值も示した。

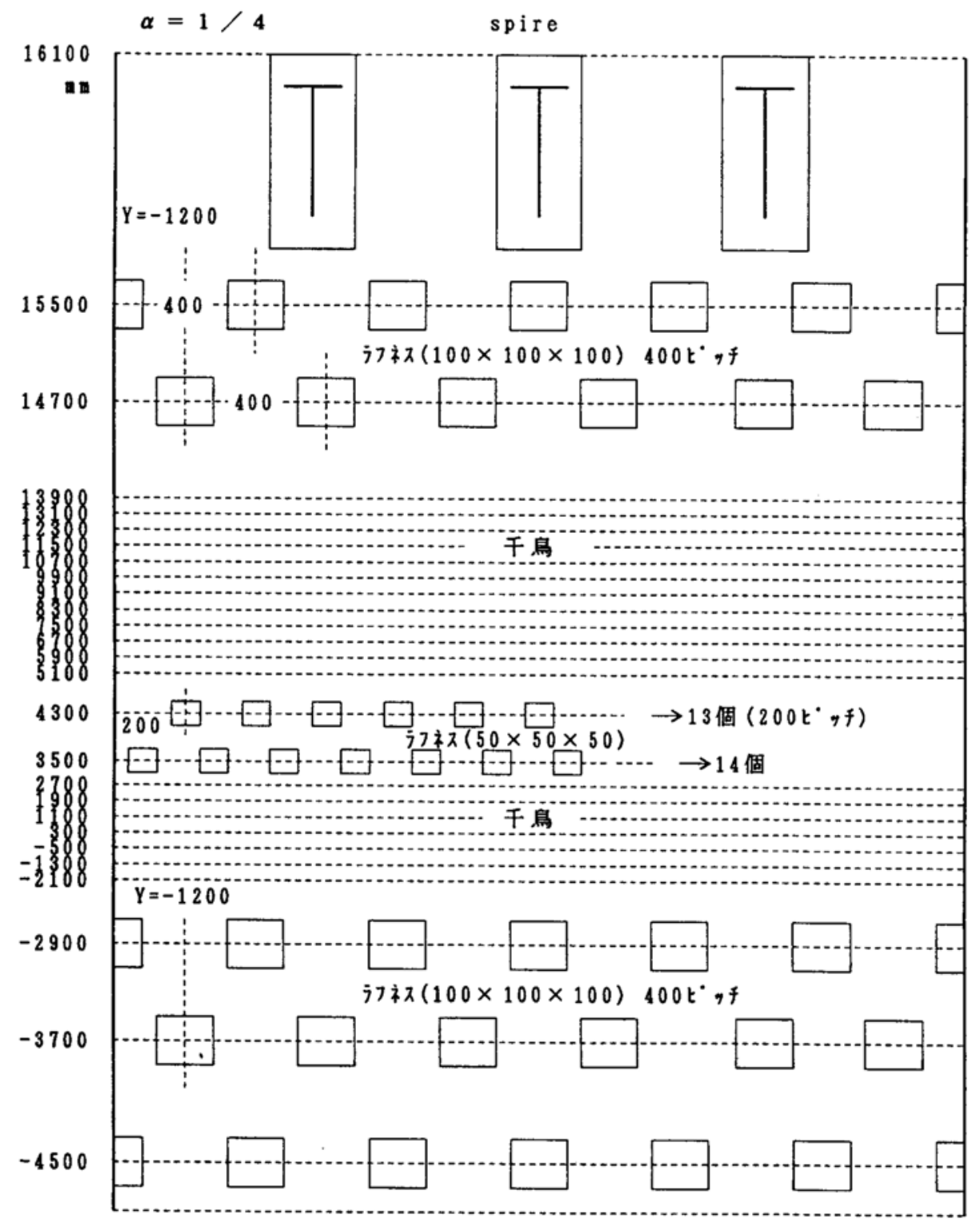

Fig. 11 べき指数 $1 / 4$ の場合のラフネスブロック配置

(Layout of the roughness blocks and the spires, power law index $=1 / 4$ ) 


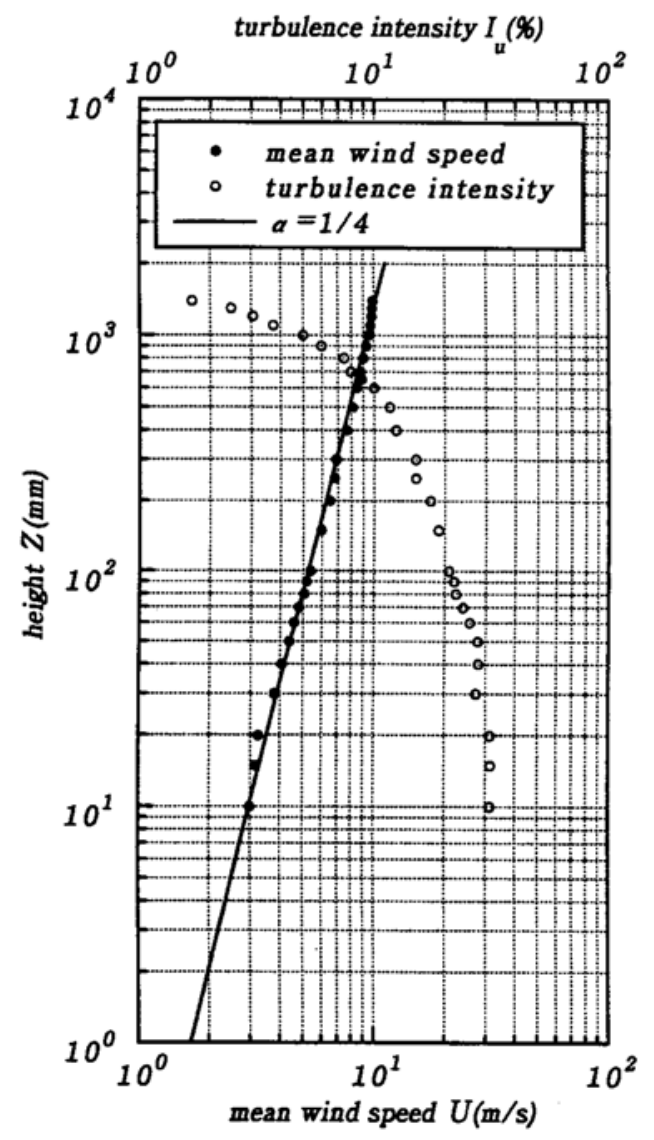

Fig. 12 気流のブロファイルと乱れの強さ (Vertical distribution of mean wind speed and turbulence intensity)

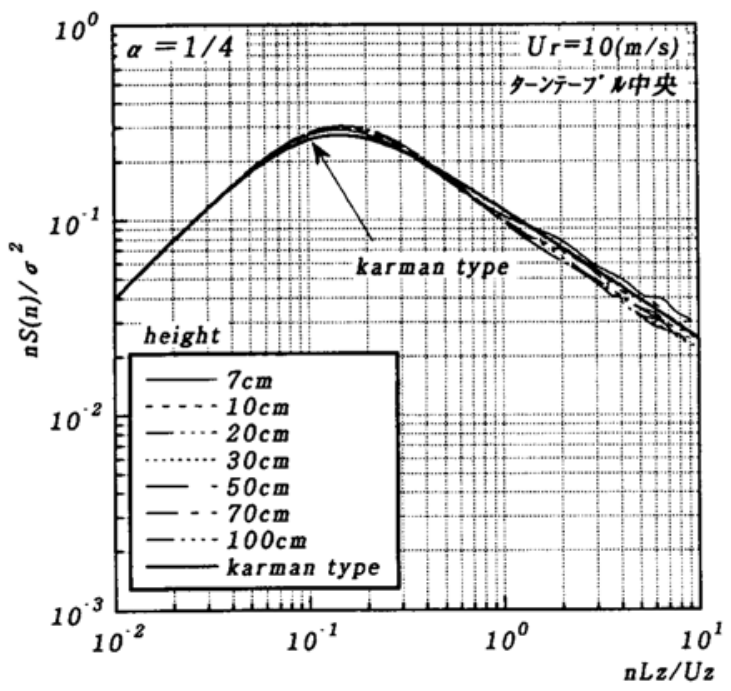

Fig. 13 変動風速のパワースペクトル密度 ( Power spectral density of wind speed fluctuation)

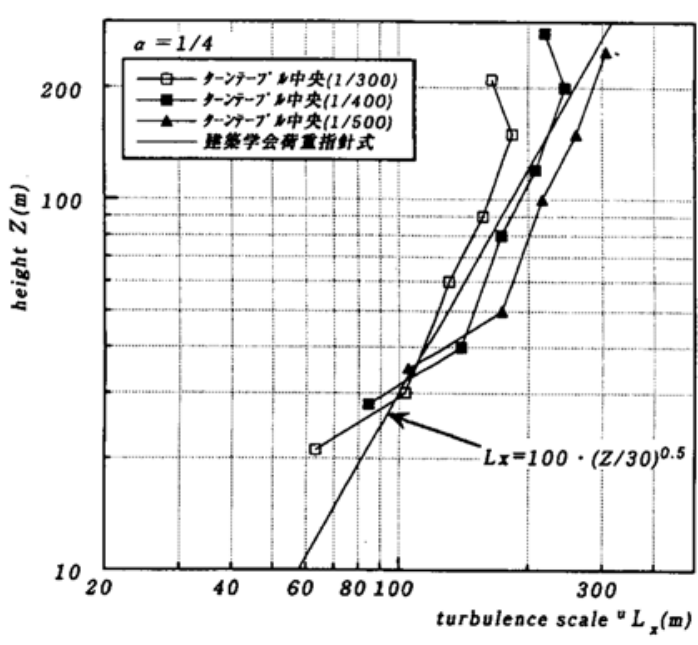

Fig. 14 乱れのスケールの鈶直分布 $\left(\mathrm{U}_{\mathrm{r}}=10 \mathrm{~m} / \mathrm{s}\right)$ (Vertical distribution of turbulence scale)

\section{おわりに}

公団八王子試験場内に新設された風洞実験施設の基 本性能について報告した。本風洞の基本性能は, 1.2 ב ンセプトの項で記した目標性能をほぼ実現できたもの と考えている。この風洞では, 平成6年末から公団各支 社からの要請に応えて風環境予測や建物外装材の風荷 重を求める実験を行っている。これらの実験について は, 早期にルーチン作業化できるように体制の確立を図 ることにしている。

又，今後は風力や風に起因する振動を対象とした実験 が実施できるように実験設備や計測・解析ソフトの整 備を進めていきたいと考えている。

\section{謝辞}

新風洞かここに紹介したような形で完成するまでに は多くの方々の協力をいただいている。

東京工芸大学田村幸雄教授，神奈川大学大能武司教授， 風工学破究所藤井邦雄所長など「風力及び振動を対象 とした風洞実験手法の開発研究委員会」3) の委員の皆様 には, 旧風洞の性能についての各種調查や新風洞の企画, 構想，性能仕様の策定に際して多大なご尽力をいただい た。風技術センター吉田正昭社長には, 基本設計から実 施設㖕, ディテールの検討の各段階において, 徽底して 使い易さにこだわった数多くの貴重なアイデアを提案 していただいた。尚, 本風洞装置は（株）風技術センター 
の設計・製造になるものであり，風洞建物の增築工事は 安藤建設が施工した。又, 本報に掲げた風洞内気流の作 成や気流性状の調查は, 泉創建エンジニヤリングの丸川 比佐夫氏が中心となって実施したものであることを最 後に記しておきたい。

本風洞の企画, 設計, 施工及び完成後の性能確認や気 流作成等の各段階でご協力いただいた数多くの関係者 の皆様に心から感謝の意を表します。

\section{参考文献}

(1) H.P.A.H.Irwin ; The Design of Spires for Wind Simulation, J.W.E. \& I.A., Vol.7, 1981, pp. $361-366$

（2）日本建築学会; 建贸物荷重指針・同解説, 1993

（3）田村, 大熊他; 風力及び振動を対象とした風洞実験 手法の開発研究報告書, 住宅・都市整满公団, 1992 